\section{RARE BOOKS AND \\ MANUSCRIPTS SECTION}

Vice-Chair/Chair-Elect: Peter E. Hanff, Coordinator, Technical Services, The Bancroft Library, University of California, Berkeley, CA 94720 (208); Richard G. Landon, Head, Thomas Fisher Rare Book Library, University of Toronto, Toronto, Ontario, Canada M5S 1 A5 (180).

Member-at-Large (three-year term): Dean H. Keller, Curator of Special Collections, Kent State University Libraries, Kent, OH 44242 (228); Donald Farren, Providence, RI 02906 (151).

\section{Slavic and East}

European SECTION

Vice-Chair/Chair-Elect: Edward Kasinec, Research Bibliographer and Librarian, Ukrainian Research Institute, Harvard University, Cambridge, MA 02138 (57); George V. Hodowanec,
Director, William Allen White Library, Emporia State University, Emporia, KS 66801 (31).

Secretary (three-year term): Kay L. Shaffer, Slavic Bibliographer/Cataloger, University Libraries, State University of New York at Albany, Albany, NY 12222 (57); Harold M. Leich, Slavic Acquisitions Librarian, University of Illinois at Urbana/Champaign, Urbana, IL 61801 (34).

Member-at-Large (one-year term): Murlin Croucher, Slavic Bibliographer, Wilson Library, University of North Carolina, Chapel Hill, NC $27514(84)$.

\section{UNIVERSITY LibRaRies SECTION}

Vice-Chair/Chair-Elect: Jean Boyer Hamlin, Librarian, Dana Library, Rutgers University, Newark, NJ 07102 (735); Rita L. Paddock, Head of Public Services, Harvard College Library, Cambridge, MA 02138 (538).

\title{
Continuing Education-V
}

\section{Philosophical Square One-and Holding}

Librarians have enthusiastically responded to the topic of continuing education with an outpouring of words and an overabundance of committees. Problem definition, a prerequisite to action, lags behind. Perhaps it will be useful to consider the ways in which four of the current $\mathrm{CE}$ controversies and dilemmas touch professionals working in academic libraries.

First, concern has been expressed that a voluntary recognition system for continuing education (such as the model being refined by CLENE) may lead to mandatory continuing education. If the mandate originates at the state level, the greatest effect would be on persons employed at state colleges and universities. However, specialized librarians (e.g., law, medicine) working in these same settings might seek recognition from a national or regional association related to their specialty. A more radical point of view is that many academic librarians are already faced with mandatory continuing education, as evidenced by the increasing number of college and university libraries that expect their professionals to have or to obtain a second master's degree.

Second, many people think that CE should be a factor in promotion, although we cannot decide which comes first-the employer should require it for promotion or the employee should expect that it be considered in promotion. Be that as it may, some college and university librarians will argue that they live in settings that have welldefined criteria for promotion and that continuing education is not one of them. Again, a slightly different point of view is that the tenure system will gradually be replaced by a contract system in which $\mathrm{CE}$ might well be an important consideration.

Third, many librarians complain that management is not interested in CE and staff develop-

\section{The Word from Colorado}

The editor of $C \& R L$ recently received this note from Ralph E. Ellsworth, director of libraries emeritus, University of Colorado, Boulder:

Several colleagues returning from the Chicago ALA Conference report that a "friend" is circulating rumors to the effect that I am: seriously ill, comatose, balmy in the grumpet, and no longer able to do consulting work. I hasten to state that I am happy, healthy, able to play daily snooker, go trout fishing and other activities common to 70 year-olds. Also, I am involved in various library building consulting activities. Having served on most of the ALA reorganization activities committees and on the intellectual freedom organization committee, I find much of the conference discussion redundant. When the dust settles, I'll start attending again. Sorry, "friend,"-Ralph E. Ellsworth. 
ment and provides no money in support of it. Although it is true that we are unsure of exactly how responsibilities should be spread among individuals, libraries, and the next largest units in which libraries are located, this is a very weak argument for academic librarians. Colleges and universities offer free or reduced tuition to their employees (admittedly, most consider only courses for credit in regular academic departments), free or reduced-rate tickets to cultural events and special programs, and convenient bookstores that may also offer discounts to faculty and staff. In many ways, one cannot help but be continually educated in the academic setting.

Fourth, for some CE advocates, the basic argument is that librarians should have wellorganized (perhaps, overorganized) CE because other professions have it. This is more than a little far-fetched. Many of the professions that have highly developed and/or required $\mathrm{CE}$ programs are the human services professions (medicine, social work, nursing, etc.) whose members deal every day with the health and well-being of clients. When will we give up trying to imitate this model? Academic librarians usually have access to collections that include materials about the history of the professions and about continuing education and lifelong learning. We should provide reference service for our colleagues in other settings.

Whether or not the above are really current topics of discussion, they are not the real issues.
We are lacking the infrastructure necessary for continuing education to become institutionalized within librarianship. And there appears to be a discrepancy of needs-differing perceptions by state agencies, professional associations, individual librarians, etc. We need to address some or all of the following topics: a university/higher education structure that facilitates CE, delivery systems that make individualized and off-campus study feasible, quality control, definition of roles for facilitators/resource persons, a clearinghouse or product evaluation mechanism for courseware and curriculum support materials, a recognition or record-keeping function, and many more.

Academic librarians will have to assume a larger role in continuing education generally, because their institutions are increasingly interested in this market. Colleges and universities will, I think, provide the basic continuing education framework for most disciplines. My primary concern is not how academic librarians will obtain continuing education, but, rather, how they will assume a role in providing it to others.-Ruth $M$. Katz, Denver Research Institute, University of Denver.

Editor's Note: Ruth Katz chairs the RASD CE Committee (ad hoc) and serves on the CLENE Advisory Committee. She has worked at the Library of Congress (Sci-Tech Div.) and Rutgers University Libraries and presently is a research scientist at the Denver Research Institute.

\section{AALS/Continuing Education Committee Resolution}

At its January 1978 convention, the membership of the Association of American Library Schools approved the following resolution on the recommendation of the Continuing Education Committee:

WHEREAS high quality library service requires a high quality staff that is continually growing and changing as the nature of library operations and librarianship changes, and

WHEREAS accomplishment of the goals of libraries requires a growing staff, and

WHEREAS the lack of organizational support has been demonstrated to inhibit staff development, while recognizing that the individual has the primary responsibility for his/her own career development,

THEREFORE, the Association of American Library Schools calls on all library bodies involved in the establishment of library standards to include a forthright statement acknowledging a library responsibility for staff development.

In brief, the position is as follows. Considering the rapid changes now occurring in libraries, staff development and continuing education programs are imperative if a library is to maintain adequate service. Initial preparation through formal education and orientation programs is not sufficient to maintain adequate staff competency. The ALA statement of policy, "Library Education and Personnel Utilization," in recognition of this fact, states, "Library administrators must accept responsibility for providing support and opportunities (in the form of leaves, sabbaticals, and released time) for the continued education of their staffs."

While library personnel retain the primary re- 